\title{
Phytochemical analysis and hepatoprotective activity of Raphanus sativus var. sativus in Sprague-Dawley rats
}

\author{
Heshu Sulaiman Rahman ${ }^{1,2 *}$, Kashan Alaalddin Bayz ${ }^{3}$, Ridha Hassan Hussein 4 , \\ Azad Ismael Abdalla ${ }^{3}$, Hemn Hassan Othman ${ }^{5}$, Kawa Mohammad Amin', \\ Rasedee Abdullah 6 \\ ${ }^{1}$ College of Medicine, Sulaimani New, University of Sulaimani, ${ }^{2}$ College of Health Sciences, Komar University of Science and \\ Technology, Sarchinar District, ${ }^{3}$ College of Agriculture, University of Sulaimani, Bakrajo District, ${ }^{4}$ College of Science, Tasluja, \\ Street 1, Zone 501, ${ }^{5}$ College of Pharmacy, Sulaimani New, University of Sulaimani, Sulaymaniyah, Republic of Iraq, ${ }^{6}$ Faculty of \\ Veterinary Medicine, Universiti Putra Malaysia, 43400, UPM Serdang, Selangor, Malaysia
}

*For correspondence: Email: heshu.rhaman@univsul.edu.iq; Tel: 0096-4772-6159598

Sent for review: 19 January 2020

Revised accepted: 20 July 2020

\begin{abstract}
Purpose: To determine the phenolic and flavonoid contents of $R$. sativus rhizome ethanol extract and the hepatoprotective effect of the extract in rats.

Methods: Folin-Ciocalteau and aluminum chloride colorimetric tests were used to determine the contents of phenols and flavonoids in the R. sativus extract. Male Sprague-Dawley rats induced with $\mathrm{CCl}_{4}$ to develop hepatotoxicity were treated orally with $\mathrm{R}$. sativus extract for 4 weeks. The antioxidant and anti-inflammatory effects of the extract on the liver were determined by evaluating the concentration of oxidative analytes, serum liver enzymes and lipids, and hepatic histopathology and cytochrome P450 2E1 expression.

Results: $R$. sativus extract significantly $(p<0.05)$ reduced the hepatotoxic effect of $\mathrm{CCl}_{4}$ via its antioxidant activities and protection of liver tissues from oxidative damage.

Conclusion: The hepatoprotective effects of $R$. sativus rhizome ethanol extract are attributed to its high phenolic and flavonoid contents.
\end{abstract}

Keywords: R. savitus rhizome, Phenols, Flavonoid contents, antioxidant, Hepatoprotective

\begin{abstract}
This is an Open Access article that uses a fund-ing model which does not charge readers or their institutions for access and distributed under the terms of the Creative Commons Attribution License (http://creativecommons.org/licenses/by/4.0) and the Budapest Open Access Initiative (http://www.budapestopenaccessinitiative.org/read), which permit unrestricted use, distribution, and reproduction in any medium, provided the original work is properly credited.

Tropical Journal of Pharmaceutical Research is indexed by Science Citation Index (SciSearch), Scopus, International Pharmaceutical Abstract, Chemical Abstracts, Embase, Index Copernicus, EBSCO, African Index Medicus, JournalSeek, Journal Citation Reports/Science Edition, Directory of Open Access Journals (DOAJ), African Journal Online, Bioline International, Open-J-Gate and Pharmacy Abstracts
\end{abstract}

\section{INTRODUCTION}

Liver diseases are become more of a health concern, accounting for approximately 2 million deaths worldwide [1]. Current drugs in use for the treatment of hepatic toxicity are associated with intolerable side effects. As alternatives, compounds from plants are being investigated to determine their usefulness in the treatment of liver diseases [2].

Among plants with potential hepatoprotective effects is the Raphanus sativus var. Sativus. The plant, commonly known as radish and belonging to the root vegetable family, Cruciferae, is originally from Europe and Asia [3]. The rhizome of the plant reportedly has other medical 
properties including prevention from development of kidney stones [3], antioxidant [4], gastroprotective [5], hypoglycemic [6], antimutagenic, hypotensive, immunoprotective [7], anticancer [8], cardiovascular protection, and antimicrobial [9] activities. The leaves and roots of $R$. sativus contain many chemical constituents, including, alkaloids, nitrogenous compounds, coumarins, enzymes, and phenols [7]

Polyphenols such as phenolics and flavonoids are known to have various healing properties including antioxidant, free radical scavenging, antioxidant enzyme secretion enhancement, and body defence towards free oxygen species activities [8]. However, the effect of $R$. sativus, with its high phenolic content, on hepatotoxicity is not known. Hepatotoxicity can be induced with carbon tetrachloride ( $\left.\mathrm{CCL}_{4}\right)$, through formation of free radicals, trichloromethyl and trichloromethyl peroxyl that induces lipid peroxidation [9].

Thus, the aim of this study is to ascertain the hepatoprotective potential of $R$. sativus on $\mathrm{CCl}_{4}-$ induced hepatotoxicity in the rat model.

\section{EXPERIMENTAL}

\section{Plant extract preparation}

The $R$. sativus plant was procured, identified and authenticated by Department of Field Crop, College of Agriculture, University of Sulaimani. Approximately, $3 \mathrm{~kg}$ of freshly harvested radish rhizome were thoroughly washed to remove contaminants, and without peeling, cubed to 1 $\mathrm{cm}^{3}$ sizes, and placed under shade at room temperature until dry. Approximately, $250 \mathrm{~g}$ of the cubes were pulverized to powder and macerated with ethanol $(1: 10 ; \mathrm{w} / \mathrm{v})$ for 5 days in a sealed vessel. The suspension was filtered using the Whatman No. 1 filter paper and the filtrate was concentrated using a rotary evaporator (Heidolph, Germany). Finally, concentrated product afforded $10.45 \mathrm{~g}$ of ethanolic extract, kept in an air-tight glass container and stored at $4{ }^{\circ} \mathrm{C}$.

\section{Evaluation of phenolic and flavonoid compounds}

Folin-Ciocalteau [10] and the aluminum chloride (AICl3) colorimetric [11] tests were used to determine the phenolic and flavonoid contents of the $R$. sativus rhizome, respectively. The phenolic content was determined by adding $1 \mathrm{~mL}$ of the extract to $1 \mathrm{~mL}$ of Folin-Ciocalteu reagent (10-fold dilution), mixed well and allowed to stand for 5 minutes at $25 \circ$ C. Then, $10 \mathrm{~mL}$ of sodium carbonate (Na2CO3; $7.5 \%$ ) solution was added to the mixture and made to a total volume of 25 $\mathrm{mL}$ with distilled water and allowed to stand for 1 hour. The absorbance was recorded at $25{ }^{\circ} \mathrm{C}$ and $765 \mathrm{~nm}$ using a spectrophotometer. The results were expressed as $\mathrm{mg}$ of Gallic acid equivalent (GAE; $5-100 \mu \mathrm{g} / \mathrm{mL}$ ) per gram of dry extract. The flavonoid content was determined by adding $1 \mathrm{~mL}$ of $2 \% \mathrm{AlCl}_{3}$ in ethanol to a mixture of $10 \mu \mathrm{L}$ of plant material and $10 \mu \mathrm{L}$ of acetic acid, made to a final volume of $25 \mathrm{~mL}$ with distilled water and allowed to stand for 45 minutes. The absorbance of the mixture was determined spectrophotometrically at $25{ }^{\circ} \mathrm{C}$ and $415 \mathrm{~nm}$ and the result expressed as $\mathrm{mg}$ of rutin equivalent (RE; $5-25 \mu \mathrm{g} / \mathrm{mL}$ ) per gram dry extract.

\section{Animal groups}

Male Sprague-Dawley rats, aged $7-8$ weeks and weighing $150 \pm 15 \mathrm{~g}$, were obtained from the Department of Clinic and Internal Medicine, College of Veterinary Medicine, University of Sulaimani. The rats, given standard rat chow and water ad libitum, were humanely managed and acclimatized under $12 \mathrm{~h}$ dark/ $12 \mathrm{~h}$ light and $25 \pm$ 3 oC ambient temperature for 1 week prior to commence of the experiment. The study was approved by the College of Veterinary Medicine, University of Sulaimani, Iraq (approval no: UNIVSUL/ACUC/2016-0909) and according to the Canadian guidelines for animal use and care [12].

\section{Induction of hepatotoxicity}

The rats were injected subcutaneously with a single dose of $1.2 \mathrm{mg} / \mathrm{kg}$ B.wt. $\mathrm{CCl}_{4}$ (SigmaAldrich, USA) in $50 \mathrm{mM}$ phosphate buffer solution (PBS). Experimentation commenced three days after the administration of $\mathrm{CCl}_{4}$.

\section{Study design and animal treatment}

Thirty male Sprague Dawley rats were randomly allotted into 5 groups of 6 animals each. Group (A) was the normal non-treated rats and served as the negative control; group (B) rats were with induced hepatotoxicity and served as vehicle control; group (C) rats were with induced hepatotoxicity, treated with $100 \mathrm{mg} / \mathrm{kg} \mathrm{B.wt}$. silymarin (hepatoprotective drug, Sigma Aldrich, St Louis, MO, USA) and served as positive control; groups (D) and (E) were rats with induced hepatotoxicity and orally treated with 50 and $100 \mathrm{mg} / \mathrm{Kg}$ B.wt. R. sativus extract, respectively. Oral treatment was done by forcefeeding rats daily for 28 consecutive days, using a ball-tipped stainless-steel needle. 


\section{Blood collection}

On day 29, $2 \mathrm{~mL}$ blood collected via cardiac puncture under general anesthesia and centrifuged at $3000 \times \mathrm{g}$ at $4{ }^{\circ} \mathrm{C}$ for 10 minutes to collect serum. Then, the animals were euthanized with an overdose of intraperiotoneal sodium thiopental. The liver was excised, washed in $0.02 \mathrm{M}$ chilled EDTA solution, fat tissues removed and subjected to the oxidative stress biomarkers content assessment and histopathology.

\section{Preparation of liver cellular fractions}

Approximately, $1 \mathrm{~g}$ of liver samples were blended with $5 \mathrm{~mL}$ of $200 \mathrm{mM}$ potassium phosphate buffer at $\mathrm{pH} 6.5$ to obtain homogenates, which were used for the determination of malonaldehyde (MDA), glutathione (GSH), superoxide dismutase (SOD), catalase (CAT), and myeloperoxidase (MPO) concentrations. The protein concentration of the homogenates was determined using the Bradford method (Bio-Rad, Hercules, CA, USA), with bovine serum albumin (BSA) $(0.125-1.0 \mathrm{mg} / \mathrm{mL})$ as the standard.

\section{Free radical and lipid peroxidation}

The MDA content of the homogenates was estimated by adding $0.5 \mathrm{~mL}$ of thiobarbituric acid reactive substance (TBARS) to each sample, heated at $100{ }^{\circ} \mathrm{C}$ for 1 hour, ice-cooled before centrifugation at $5000 \times \mathrm{g}$ for 15 minutes. The absorbance of the supernatants was estimated spectrophotometrically at $37 \circ^{\circ} \mathrm{C}$ and $535 \mathrm{~nm}$ using 1,1,3,3- tetraethoxypropane as the standard. The results were expressed as $\mathrm{nmol} / \mathrm{mg}$ protein.

The SOD was determined by mixing $1 \mathrm{~mL}$ of homogenate with $500 \mu \mathrm{L} 200 \mathrm{mM}$ Tris $\mathrm{HCl}-$ EDTA buffer solution at $\mathrm{pH} 8.5$ and allowing for equilibration for 1 minute before incubating at 25 ${ }^{\circ} \mathrm{C}$ for 18 minutes. The reaction was stopped by adding $0.1 \mathrm{~mL} 1 \mathrm{~N} \mathrm{HCl}$ to the mixture centrifuging at $15000 \times \mathrm{g}$. The absorbance of the supernatant was read spectrophotometrically at $37{ }^{\circ} \mathrm{C}$ and $405 \mathrm{~nm}$. The amount of SOD that suppressed the auto-oxidation of pyrogallol by $50 \%$ was expressed as U/mg protein [13].

The concentration of GSH was determined by mixing $1 \mathrm{~mL}$ of homogenate with $1 \mathrm{~mL} 12.5 \%$ trichloroacetic acid and allowed to equilibrate for 8 minutes before centrifuging for 10 minutes at $1000 \times \mathrm{g}$. The supernatant collected was mixed with $2 \mathrm{~mL} 0.4 \mathrm{M}$ TRIS buffer at $\mathrm{pH} 8.9$ ) and $1 \mathrm{~mL}$ $0.01 \mathrm{M}$ dinitro-thiobenzoic acid (DTNB). The absorbance of the supernatant was read spectrophotometrically at $25^{\circ} \mathrm{C}$ and $420 \mathrm{~nm}$. The GSH concentration expressed as $\mathrm{nmol} / \mathrm{mg}$ of tissue was determined from GSH standard curved prepared.

About $1 \mathrm{~mL}$ of homogenate was centrifuged at $15000 \times \mathrm{g}$ to collect supernatant. The CAT was determined by mixing $1 \mathrm{~mL}$ of supernatant with 1 $\mathrm{mL}$ of solution containing $200 \mathrm{mM}$ Tris $\mathrm{HCl}-$ EDTA buffer solution of $\mathrm{pH} 8.5$ and $0.5 \mathrm{~mL}$ $20 \mathrm{mM} \mathrm{H}_{2} \mathrm{O}_{2}$ of $\mathrm{pH}$ 7.0. Then, the absorbance was read spectrophotometrically at $37^{\circ} \mathrm{C}$ and $240 \mathrm{~nm}$ and the results expressed as $\mu \mathrm{mol} / \mathrm{mg}$ protein [14].

\section{Anti-inflammatory evaluation}

The hepatic MPO activity was determined by adding $1 \mathrm{~mL}$ homogenate to $1 \mathrm{~mL} 80 \mathrm{mM}$ potassium phosphate buffer $(\mathrm{pH} 5.4)$ containing $0.5 \%$ hexadecyl-trimethyl-ammonium bromide (HTAB). The mixture was centrifuged at $15000 \times$ $\mathrm{g}$ for 15 minutes at $4{ }^{\circ} \mathrm{C}$. The absorbance of the supernatant was determined at at $37{ }^{\circ} \mathrm{C}$ and $620 \mathrm{~nm}$ and the concentration of MPO was expressed as absorbance/mg of protein using $0.0625 \mathrm{mg} / \mathrm{mL}$ albumin as the standard [15].

\section{Lipid profile and serum biochemical analysis}

Serum total cholesterol (TC), triglyceride (TG), low density lipoprotein (LDL), high density lipoprotein (HDL), very low density lipoprotein (VLDL), urea, creatinine, alanine aminotransferase (ALT), aspartate aminotransferase (AST), lactate dehydrogenase $(\mathrm{LDH})$, total protein (TP), alkaline phosphatase (ALP), and total bile acids (TBA) were determined using commercial kits (Roche) and the Hitachi Chemistry Analyzer (Hitachi HighTechnologies Corporation, Japan).

\section{Histopathology analysis of liver}

Fresh liver tissues were trimmed, placed in plastic cassettes and fixed in $10 \%$ formalin. After 48 hours, tissues were processed, infiltrated in paraffin, sectioned to a thickness of $5 \mathrm{~mm}$, deparaffinized and rehydrated. Finally, the sections were stained with hematoxylin and eosin, viewed under light microscopy (Leica, Japan) and the histological changes in the liver sections recorded.

\section{Western blotting}

The expression of liver cytochrome P450 E1 (CYP2E1) was determined by mixing $0.5 \mathrm{~mL}$ of liver homogenate with $1 \quad \mathrm{~mL}$ radioimmunoprecipitation assay (RIPA) buffer 
and $10 \mu \mathrm{L}$ protease inhibitor cocktail (Pierce, Thermo Fisher Scientific, USA) to lyse the cells. The mixture was centrifuged at $15000 \times \mathrm{g}$ to obtain supernatant. The protein concentration of the supernatant was determined using the Bradford method (Bio-Rad, Hercules, CA, USA), with bovine serum albumin (BSA) $(0.125-1.0$ $\mathrm{mg} / \mathrm{mL}$ ) as the standard. The SDS PAGE (BioRad, USA) was used to separate proteins in the supernatant. The separated protein transferred by blotting to the nitrocellulose membrane (PALL, USA) and blocked with $5 \%$ skimmed milk (Biobasic, USA) for 24 hours, washed with TBST (pH 7.6), and flooded with CYP2E1 (Abcam, USA) for 1 hour at $4^{\circ} \mathrm{C}$. GAPDH was used as the housekeeping protein. The membrane was rinsed and flooded with horse radish peroxidase substrate for 10 minutes. Lastly, the membrane was visualised with the Chemidoc imager (UVP, USA) and the Vision Work LS Analysis software (UVP, USA) was used to analyse the result.

\section{Statistical analysis}

The data were subjected to statistical analysis using one-way analysis of variance (ANOVA) followed by Tukey multiple comparison tests (SPSS version 23.0, Chicago, USA) and the results expressed as mean $\pm S D(n=3)$. Probability values of $p<0.05$ were considered statistically significant.

\section{RESULTS}

\section{Phytochemical profile}

The of $R$. sativus ethanol extract contained $145.91 \pm 0.18 \mathrm{mg} \mathrm{GAE} / \mathrm{g}$ phenolic and $21.95 \pm$ $1.2 \mathrm{mg} \mathrm{RE} / \mathrm{g}$ flavonoid compounds.

\section{Lipid peroxidation}

The study showed that oral supplementation of rats with $R$. sativus extract and silymarin treatment decreased the GSH and MDA content $(p<0.05)$ and increased the SOD and CAT activities $(p<0.05)$ in liver tissues, in comparison with the vehicle group. The $R$. sativus extract at various doses also decreased liver MPO activity significantly $(p<0.05)$ in comparison with the positive control (Table 1).

\section{Lipid profile}

Rats of the vehicle group showed significant $(p<$ 0.05) higher serum TC, TG, LDL, and VLDL levels and lower $(p<0.05) \mathrm{HDL}$ level than the silymarin and $R$. sativus extract treatment groups (Table 2). The high LDL/HDL ratio in the vehicle group and to lesser extent in treated groups may point to incipient atherosclerotic complications. At the same time, the high TG level in the vehicle group is related to the fatty degeneration of the liver.

\section{Biochemical profile}

$R$. sativus significantly $(p<0.05)$ prevented the $\mathrm{CCl}_{4}$ evoked raising of serum AST, ALT, ALP, $\mathrm{LDH}$, and urea while significantly $(p<0.05)$ restored the levels of serum TBA, TP and creatinine in dosed rats. The silymarin group also displayed significant $(p<0.05)$ protective covering toward $\mathrm{CCl} 4$-induced liver impairment through the previous-mentioned biomarkers (Table 3).

\section{Histopathological features}

The liver tissues of the control negative group rats demonstrated normal morphology with intact hepatic cells and a central vein. In opposite to this, the vehicle group showed marked hepatic injury including massive fatty changes, necrosis, degeneration, infiltration of lymphocytes, cellular hypertrophy, and the loss of cellular boundaries. On the other hand, changes improved greatly in silymarin treated rats, which displayed almost as of normal liver appearance. Additionally, treatment with $R$. sativus markedly attenuated CCl4-induced liver damage and showed normal lobular outline with a slight fatty change, necrosis, and inflammatory cells (Figure 1).

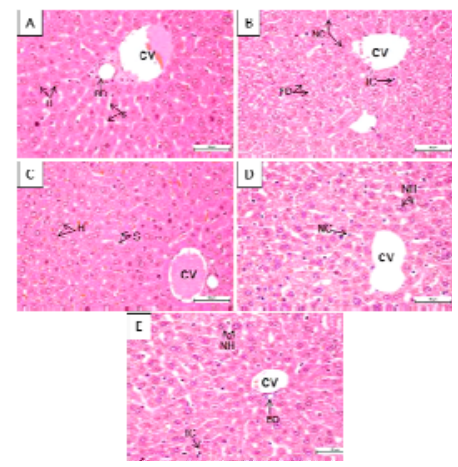

Figure 1: Liver section of male Sprague-Dawley rats. (A) Negative control showing normal liver morphology; (B) Vehicle control showing massive fatty degeneration and necrotic and inflammatory cells; (C) $100 \mathrm{mg} / \mathrm{kg}$ Silymarin treatment showing some hepatocyte regeneration; (D) $50 \mathrm{mg} / \mathrm{kg} R$. sativus treatment showing normally arranged hepatocytes, very few necrotic cells, and moderate fatty change; $(E)$ $100 \mathrm{mg} / \mathrm{kg} \mathrm{R}$. sativus treatment showing intact hepatocytes and very few inflammatory cells, minimal fatty change. CV - Central vein, $\mathrm{H}$ - Hepatocyte, BD Bile duct, S - Sinusoid, NC - Necrotic cell, FD - Fatty degeneration, IC - Inflammatory cell. Hematoxylin and Eosin stain. Magnification: 100x 
Table 1: Effect of $R$. sativus aqueous extract on liver homogenate lipid peroxidation and anti-inflammatory parameters of normal and $\mathrm{CCl}_{4}$-induced hepatotoxic rats.

\begin{tabular}{|c|c|c|c|c|c|}
\hline Treatment & $\begin{array}{c}\text { MDA } \\
\text { (nmol/mg) }\end{array}$ & $\begin{array}{c}\text { GSH } \\
\text { (nmol/mg) }\end{array}$ & $\begin{array}{c}\text { SOD } \\
\text { (U/mg) }\end{array}$ & $\begin{array}{c}\text { CAT } \\
\text { (U/mg) }\end{array}$ & $\begin{array}{c}\text { MPO } \\
\text { (abs/mg) }\end{array}$ \\
\hline Normal control & $2.25 \pm 1.11$ & $12.7 \pm 0.85$ & $12.5 \pm 0.75$ & $28.04 \pm 0.43$ & $0.10 \pm 0.05$ \\
\hline Vehicle control & $4.4 \pm 0.52^{*}$ & $19.9 \pm 0.44^{*}$ & $6.6 \pm 0.15^{\star}$ & $15.31 \pm 0.67^{*}$ & $0.17 \pm 0.04^{*}$ \\
\hline Positive control & $2.85 \pm 0.55^{\star *}$ & $13.05 \pm 0.65^{\star *}$ & $10.9 \pm 0.28^{* *}$ & $22.45 \pm 0.55^{\star *}$ & $0.121 \pm 0.05^{\star *}$ \\
\hline \multicolumn{6}{|l|}{ R. savitus extract } \\
\hline 50 mg/kg B.wt. & $3.3 \pm 0.42^{* *}$ & $14.1 \pm 0.75^{\star *}$ & $9.4 \pm 0.45^{\star *}$ & $17.9 \pm 0.61^{* *}$ & $0.13 \pm 0.02^{* *}$ \\
\hline 100 mg/kg B.wt. & $3.0 \pm 0.03^{\star *}$ & $13.0 \pm 0.25^{\star *}$ & $10.3 \pm 0.77^{\star *}$ & $20.75 \pm 0.23^{* *}$ & $0.125 \pm 0.1^{* *}$ \\
\hline
\end{tabular}

Values are expressed as mean $\pm \mathrm{SD} ; \mathrm{N}=6$. Normal control - Non-treated; vehicle control - carbon tetrachloride $\left(\mathrm{CCl}_{4}\right.$ )-induced hepatotoxicity without; Positive control - $\mathrm{CCl}_{4}$-induced hepatotoxicity with $100 \mathrm{mg} / \mathrm{kg} \mathrm{B.wt}$. silymarin treatment; $R$. savitus extract - $\mathrm{CCl}_{4}$-induced hepatotoxicity with extract treatment. MDA malonaldehyde; GSH - gluthatione; SOD - superoxide dismutase; CAT - catalase; MPO - myeloperoxide. *Significance level: $p<0.05$, compared to normal control. ${ }^{*}$ Significance level: $p<0.05$, compared to vehicle control.

Table 2: Effect of $R$. sativus aqueous extract on liver homogenate lipid profile of normal and $\mathrm{CCl}_{4}$-induced hepatotoxic rats.

\begin{tabular}{|c|c|c|c|c|c|}
\hline Treatment & $\begin{array}{c}\mathrm{TC} \\
\text { (mg/dL) }\end{array}$ & $\begin{array}{c}\mathrm{TG} \\
(\mathrm{mg} / \mathrm{dL})\end{array}$ & $\begin{array}{c}\mathrm{LDL} \\
\text { (mg/dL) }\end{array}$ & $\begin{array}{c}\mathrm{HDL} \\
\text { (mg/dL) }\end{array}$ & $\begin{array}{c}\text { VLDL } \\
\text { (mg/dL) }\end{array}$ \\
\hline Normal control & $80.76 \pm 1.23$ & $112.50 \pm 2.55$ & $24.25 \pm 1.27$ & $52.61 \pm 1.15$ & $18.33 \pm 0.48$ \\
\hline Vehicle control & $127.5 \pm 2.17^{*}$ & $225.05 \pm 1.72^{*}$ & $101.09 \pm 3.02^{*}$ & $29.45 \pm 1.01^{*}$ & $35.54 \pm 0.77^{*}$ \\
\hline Positive control & $84.33 \pm 1.06^{* *}$ & $130.14 \pm 1.32^{* *}$ & $55.22 \pm 4.15^{\star *}$ & $40.04 \pm 1.25^{\star *}$ & $20.97 \pm 0.49^{* *}$ \\
\hline \multicolumn{6}{|l|}{ R. savitus extract } \\
\hline 50 mg/kg B.wt. & $89.22 \pm 3.02^{\star *}$ & $145.09 \pm 3.03^{* *}$ & $64.36 \pm 2.30^{* *}$ & $43.18 \pm 0.77^{* *}$ & $23.45 \pm 0.52^{\star \star}$ \\
\hline 100 mg/kg B.wt. & $83.43 \pm 1.12^{* *}$ & $127.23 \pm 3.10^{* *}$ & $57.55 \pm 2.01^{* *}$ & $48.10 \pm 1.24^{* *}$ & $25.31 \pm 0.65^{\star *}$ \\
\hline
\end{tabular}

Values are expressed as mean $\pm \mathrm{SD} ; \mathrm{N}=6$. Normal control - Nontreated; Vehicle control - Carbon tetrachloride $\left(\mathrm{CCl}_{4}\right)$-induced hepatotoxicity without treatment; Positive control - $\mathrm{CCl}_{4}$-induced hepatotoxicity with $100 \mathrm{mg} / \mathrm{kg}$ B.wt. silymarin treatment; $R$. savitus extract - $\mathrm{CCl}_{4}$-induced hepatotoxicity with extract treatment. TC - Total cholesterol; TG - Triglyceride; LDL - Low density lipoprotein; HDL - High density lipoprotein; VLDL - Very lowdensity lipoprotein (VLDL). *Significance level: $p<0.05$, compared to normal control. ${ }^{* *}$ Significance level: $p<$ 0.05 , compared to vehicle control

Table 3: Effect of $R$. sativus aqueous extract on serum biochemical parameters of normal and $\mathrm{CCl}_{4}$-induced hepatotoxic rats

\begin{tabular}{|c|c|c|c|c|c|c|c|c|}
\hline Treatment & $\begin{array}{c}\text { Urea } \\
(\mathrm{mmol} / \mathrm{L})\end{array}$ & $\begin{array}{c}\text { Creatinine } \\
(\mu \mathrm{m} / \mathrm{L})\end{array}$ & $\begin{array}{l}\text { LDH } \\
\text { (U/L) }\end{array}$ & $\begin{array}{l}\text { AST } \\
\text { (U/L) }\end{array}$ & $\begin{array}{l}\text { ALT } \\
\text { (U/L) }\end{array}$ & $\begin{array}{l}\text { ALP } \\
\text { (U/L) }\end{array}$ & $\begin{array}{c}\text { TBA } \\
\text { (mg/dL) }\end{array}$ & $\begin{array}{c}\text { TP } \\
(\mathrm{mg} / \mathrm{dL})\end{array}$ \\
\hline $\begin{array}{l}\text { Normal } \\
\text { control }\end{array}$ & $\begin{array}{c}8.45 \pm \\
0.30\end{array}$ & $\begin{array}{c}66.25 \pm \\
2.0\end{array}$ & $455 \pm 13$ & $\begin{array}{c}81.40 \pm \\
2.10\end{array}$ & $\begin{array}{c}49.01 \pm \\
2.30\end{array}$ & $\begin{array}{c}155.60 \pm \\
2.50\end{array}$ & $\begin{array}{c}0.27 \pm \\
1.60\end{array}$ & $\begin{array}{c}7.05 \pm \\
1.12\end{array}$ \\
\hline $\begin{array}{l}\text { Vehicle } \\
\text { control }\end{array}$ & $\begin{array}{c}11.50 \pm \\
0.50^{*}\end{array}$ & $\begin{array}{c}50.75 \pm \\
1.49^{*}\end{array}$ & $\begin{array}{c}583 \pm \\
19^{*}\end{array}$ & $\begin{array}{c}295.40 \pm \\
3.00^{*}\end{array}$ & $\begin{array}{c}158.03 \pm \\
0.59^{*}\end{array}$ & $\begin{array}{c}345.30 \pm \\
2.10^{*}\end{array}$ & $\begin{array}{c}0.80 \pm \\
2.40^{*}\end{array}$ & $\begin{array}{c}4.35 \pm \\
2.30^{*}\end{array}$ \\
\hline $\begin{array}{l}\text { Positive } \\
\text { control }\end{array}$ & $\begin{array}{l}8.90 \pm \\
0.34^{\star *}\end{array}$ & $\begin{array}{c}60.65 \pm \\
2.75^{\star *}\end{array}$ & $\begin{array}{c}469.2 \pm \\
5.45^{\star *}\end{array}$ & $\begin{array}{c}100.88 \pm \\
2.10^{* *}\end{array}$ & $\begin{array}{c}80.46 \pm \\
1.10^{* *}\end{array}$ & $\begin{array}{c}203.52 \pm \\
3.30^{* *}\end{array}$ & $\begin{array}{l}0.55 \pm \\
2.11^{* *}\end{array}$ & $\begin{array}{l}6.55 \pm \\
3.00^{\star *}\end{array}$ \\
\hline \multicolumn{9}{|l|}{$\begin{array}{l}R \text {. savitus } \\
\text { extract }\end{array}$} \\
\hline $\begin{array}{l}50 \\
\mathrm{mg} / \mathrm{kg} \\
\text { B.wt. }\end{array}$ & $\begin{array}{l}9.55 \pm \\
0.57^{\star *}\end{array}$ & $\begin{array}{c}54.95 \pm \\
1.92^{* *}\end{array}$ & $\begin{array}{c}495 \pm \\
16^{\star \star}\end{array}$ & $\begin{array}{c}155.37 \pm \\
1.50^{* \star}\end{array}$ & $\begin{array}{c}111.65 \pm \\
3.12^{\star *}\end{array}$ & $\begin{array}{c}269.97 \pm \\
1.45^{* *}\end{array}$ & $\begin{array}{c}0.71 \pm \\
2.09\end{array}$ & $\begin{array}{l}5.39 \pm \\
2.20^{* *}\end{array}$ \\
\hline $\begin{array}{l}100 \\
\mathrm{mg} / \mathrm{kg} \\
\text { B.wt. }\end{array}$ & $\begin{array}{l}9.00 \pm \\
0.57^{\star \star}\end{array}$ & $\begin{array}{c}58.90 \pm \\
1.10^{\star *}\end{array}$ & $\begin{array}{c}478 \pm \\
11^{* *}\end{array}$ & $\begin{array}{c}119.15 \pm \\
1.30^{* *}\end{array}$ & $\begin{array}{c}90.76 \pm \\
2.80^{\star *}\end{array}$ & $\begin{array}{c}228.55 \pm \\
1.15^{\star *}\end{array}$ & $\begin{array}{l}0.64 \pm \\
3.20^{\star \star}\end{array}$ & $\begin{array}{l}5.88 \pm \\
2.33^{\star \star}\end{array}$ \\
\hline
\end{tabular}

Values are expressed as mean $\pm \mathrm{SD} ; \mathrm{N}=6$. Normal control - Nontreated; Vehicle control - Carbon tetrachloride $\left(\mathrm{CCl}_{4}\right.$ )-induced hepatotoxicity.without treatment; Positive control - $\mathrm{CCl}_{4}$-induced hepatotoxicity with $100 \mathrm{mg} / \mathrm{kg}$ B.wt. silymarin treatment; $R$. savitus extract - $\mathrm{CCl}_{4}$-induced hepatotoxicity with extract treatment. LDH - Lactate dehydrogenase; AST - Asparate aminotransferase; ALT - Alanine aminotransferase; ALP - Alkaline phosphatase; TBA - Total bile acids; TP - Total protein. *Significance level: $p<0.05$, compared to normal control. ${ }^{*}$ Significance level: $p<0.05$, compared to vehicle control 


\section{Protein expressions}

The non-treated rats showed lowest expression of liver cytochrome P450 2E1 among treatment groups. The highest hepatic cytochrome P450 $2 \mathrm{E} 1$ expression was in the vehicle group of rats. The positive control and $R$. sativus -treated rats showed significantly $(p<0.05)$ lower hepatic cytochrome P450 2E1 expressions than the vehicle group (Figure 2).

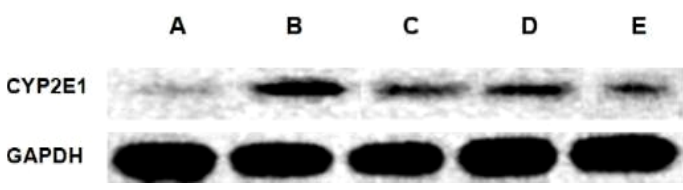

Figure 2: Western blot expression of CYP2E1 and GAPDH proteins in fresh liver tissues of treatment rats. (A) Normal control; (B) Negative control; (C) Carbon tetrachloride $\left(\mathrm{CCl}_{4}\right)$-induced hepatotoxic liver tissues treated with $50 \mathrm{mg} / \mathrm{kg}$ silymarin; CCl4-induced hepatotoxic liver tissues treated with (D) $50 \mathrm{mg} / \mathrm{kg}$ and (C) $100 \mathrm{mg} / \mathrm{kg} R$. sativus extract

\section{DISCUSSION}

The study showed that the $R$. sativus extract has high phenolic and flavonoid compound contents. This finding, with some variation, is similar to that reported by others on various species of radish rhizomes such as in $R$. sativus L., $R$. sativus $L$. cultivars Cherry Belle and Valentine [16, 17]. The variations in phenolic and flavonoid contents of $R$. sativus among these studies are attributed to the differences in species, chemodiversity, breeding condition, ontogenetic status, stage of maturation, degradation, and post-harvest handling [17]. Phenolic and flavonoid compounds have antioxidant properties that exert actions either directly through interactions with toxic oxygen species or indirectly by increasing the activities of tissue antioxidant enzymes [18].

Several extracts from natural plants such as Maytenus robusta Reiss [19], Phyllanthus amarus [20], Fagonia schweinfurthii Hadidi [21], and Herpetospermum caudigerum [22] were shown to protect the liver from oxidant damage induced with $\mathrm{CCl}_{4}$. In our study, we showed that administration of $R$. sativus significantly decreased the activities of the oxidants, MDA, and $\mathrm{GSH}$, while increasing the activities of antioxidant enzymes, SOD and CAT in $\mathrm{CCl}_{4}$ induced hepatotoxicity in rats. The results suggest that the $R$. sativus extract is a potent compound for the protection of the liver from oxidative damage.

Treatment of rats with $\mathrm{CCl}_{4}$ had caused liver damage as evident by significant increases in concentration of serum leakage of liver enzymes, ALT, AST, and LDH. However, $R$. sativus prevented the $\mathrm{CCl}_{4}$ induced ascension of serum AST, ALT, ALP, LDH, and urea in treated rats. This suggests that the $R$. sativus extract is hepatoprotective.

Histopathologically, $\mathrm{CCl}_{4}$ caused fatty degeneration and infiltration of inflammatory cells in the rats. Even after treatment with silymarin, a known hepatoprotective drug, the liver of $\mathrm{CCl}_{4}$ treated rats still showed some hepatocellular degeneration. $R$. sativus extract is a good hepatoprotective agent because this compound had reduced the histopathological changes in the rat liver tissues induced by $\mathrm{CCl}_{4}$. In fact, in rats, $R$. sativus extract had dose-dependently reduced the $\mathrm{CCl}_{4}$-induced hepatotoxicity to minimal fatty changes with infiltration of only a few inflammatory cells, suggesting that it is even a better hepatoprotective compound than silymarin.

Lipids are primarily produced by the liver and intestinal enterocytes. Among the causes of hyperlipidemia is cholestatic Liver disease. Liver disease can cause hypercholesterolaemia, from failure of the organ to metabolize circulating cholesterol. In this study, $\mathrm{CCl}_{4}$ injection increased serum TC, TG, LDL, and VLDL but not $\mathrm{HDL}$ in rats. However, treatment with $R$. sativus extract caused decrease in serum TG, LDL, VLDL, and increase in HDL and HDL: LDL. This finding is similar to that report by other researchers [23]. The extract does not only protect the liver from oxidant damage but also has the potential to reduce risk of development of cardiovascular disorders in patients with hepatic diseases.

Cytochrome P450-2E1 or CYP2E1 is a membrane-bound protein found in high concentration in the liver. CYP2E1 catalyzes transformation of organic molecules, fatty acids, ketones, glycerol, drugs such as salicylic acid, halothane, and isoniazid, $\mathrm{CCl}_{4}$, chloroform, and environmental contaminants such as benzene and acrylamide. Increased expression of hepatic tissue CYP2E1 is associated with oxidative liver damage and hepatotoxicity [24, 25]. In our study, the highest expression of hepatic tissue CYP2E1 was in the rats with $\mathrm{CCl}_{4}$ hepatocytotoxicity. Treatment with $R$. sativus extract had dosedependently decreased expression of this protein in the rat liver.

\section{CONCLUSION}

The findings of this study show that $R$. sativus extract lowers the hepatotoxic effect of oxidant 
compounds produced by the action of $\mathrm{CCl}_{4}$. The antioxidant and hepatoprotective effects of $R$. sativus extract is suggested is here attributed to its phenolic and flavonoid contents. The antioxidant effect of $R$. sativus extract is primarily due to its capacity to suppress lipid peroxidation, stimulate tissue free radical scavenging and enzymatic antioxidant activities. These properties protect the liver from the tissue-damaging actions of reactive oxygen species (ROS) and subsequent inflammatory response.

\section{DECLARATIONS}

\section{Acknowledgement}

The authors are grateful to the Research Center Laboratory and Animal House, College of Veterinary Medicine, University of Sulaimani, Iraq for providing of laboratory facilities. Additionally, the authors would like to appreciate the Department of Veterinary Laboratory Diagnosis, Faculty of Veterinary Medicine, Universiti Putra Malaysia for providing technical knowledge, assistance and facilities for this study. No specific grant was received for this research but partially sponsored by MOSTI (Grant no. 5495308).

\section{Conflict of interest}

No conflict of interest is associated with this work.

\section{Contribution of authors}

We declare that this work was done by the authors named in this article and all liabilities pertaining to claims relating to the content of this article will be borne by the authors.

\section{Open Access}

This is an Open Access article that uses a funding model which does not charge readers or their institutions for access and distributed under the terms of the Creative Commons Attribution License (http://creativecommons.org/licenses/by/ 4.0) and the Budapest Open Access Initiative (http://www.budapestopenaccessinitiative.org/rea d), which permit unrestricted use, distribution, and reproduction in any medium, provided the original work is properly credited.

\section{REFERENCES}

1. Asrani SK, Devarbhavi H, Eaton J, Kamath PS. Burden of liver diseases in the world. Hepatol 2019: 151-171.
2. Rajaratnam M, Prystupa A, Lachowska-Kotowska $P$, Zuluska W, Filip R. Herbal medicine for treatment and prevention of liver diseases 2014; J Preclin Clin Res, 8(2): 55-60.

3. Stuart G. (2014). Raphanus sativus-StuartXchange: www.stuartxchange.com/Labanos. Html.

4. Barillari J, Cervellati R, Costa S, Guerra MC, Speroni E, Utan A, lori R. Antioxidant and choleretic properties of Raphanus sativus L. sprout (Kaiware Daikon) extract. J Agric Food Chem 2006; 54(26): 9773-9778.

5. Alqasoumi S, Al-Yahya M, Al-Howiriny T, and Rafatullah S. Gastroprotective effect of radish Raphanus sativus $L$. on experimental gastric ulcer models in rats. FarmaciaBucuresti 2008; 56(2): 204-214.

6. Taniguchi H, Kobayashi-Hattori K, Tenmyo C, Kamei $T$, Uda Y, Sugita-Konishi Y, Oishi Y, Takita T. Effect of Japanese radish (Raphanus sativus) sprout (Kaiware-daikon) on carbohydrate and lipid metabolisms in normal and streptozotocin-induced diabetic rats. Phytother Res 2006; 20(4): 274-278.

7. Gutiérrez RM, Perez RL. Raphanus sativus (Radish): their chemistry and biology. The Sci World J 2004; 4: 811-837.

8. Hanlon PR, Barnes DM. Phytochemical composition and biological activity of 8 varieties of radish (Raphanus sativus L.) sprouts and mature taproots. J Food Sci 2011; 76(1): 185-192.

9. Nakamura $Y$, Iwahashi T, Tanaka A, Koutani, Matsuo $T$, Okamoto S, Sato K, Ohtsuki K. 4-(Methylthio)-3-butenyl isothiocyanate, a principal antimutagen in daikon (Raphanus sativus; Japanese white radish). J Agric Food Chem 2001; 49(12): 5755-5760.

10. Singleton V, Orthofer R, Lamuela-Raventos RA. Analysis of total phenols and other oxidation substrates and antioxidants by means of Folin-Ciocalteu reagent. Meth Enzymol 1999; 299: 152-175.

11. Chouhan HS, Singh SK. Phytochemical analysis, antioxidant and anti-inflammatory activities of Phyllanthus simplex. J Ethnopharmacol 2011; 137: 1337-1344.

12. Canadian Council on Animal Care; http://www.ccac.ca

13. Rahman HS, Rasedee A, How CW, Zeenathul NA, Chartrand MS, Yeap SK, Abdul AB, Tan SW, Othman $H H$, Ajdari $Z$ et al. Antileukemic effect of zerumboneloaded nanostructured lipid carrier in WEHI-3B cellinduced murine leukemia model. Int J Nanomed 2015; 10: 1649-1666.

14. Mohamad NE, Yeap SK, Lim KL, Yusof HM, Beh BK, Tan SW, Ho WY, Sharifuddin SA, Jamaluddin A, Long $K$ et al. Antioxidant effects of pineapple vinegar in reversing of paracetamol-induced liver damage in mice. Chin Med J 2015; 10: 1-14.

15. Tsouvaltzis $P$, Brecht JK. Changes in quality and antioxidant enzyme activities of bunched and topped radish (Raphanus sativus $L$.) plants during storage at 5 or $10^{\circ} \mathrm{C}$. J Food Qual 2014; 157-167.

16. Tsouvaltzis $P$, Brecht JK. Changes in quality and antioxidant enzyme activities of bunched and topped

Trop J Pharm Res, August 2020; 19(8): 1751 
radish (Raphanus sativus L.) plants during storage at 5 or $10^{\circ} \mathrm{C}$. J Food Qual 2014; 157-167.

17. Kim JK, Baskar TB, Park SU. Total Phenolic and Flavonoid Contents and Antioxidant Activities of Two Raphanus sativus L. cultivars (Cherry Belle and Valentine). Biosci Biotechnol Res Asia 2016; 13(1): 3136.

18. Kasote DM, Katyare SS, Hegde MV, Bae H. Significance of antioxidant potential of plants and relevance to therapeutic applications. Int. J Biol Sci 2015; 11(8): 982991.

19. Thiesen LC, da Silva LM, Santin JR, Bresolin TM, de Andrade SF, de Medeiros Amorim C, Merlin L, de Freitas RA, Niero R, Netz DJ. Hepatoprotective effect of Maytenus robusta Reiss extract on $\mathrm{CCl}_{4}$-induced hepatotoxicity in mice and HepG2 cells. Regul Toxicol Pharm 2017; 86: 93-100.

20. Krithika R, Mohankumar R, Verma RJ, Shrivastav PS, Mohamad IL, Gunasekaran P, Narasimhan S. Isolation, characterization and antioxidative effect of phyllanthin against CCl4-induced toxicity in HepG2 cell line. Chem Biol Interact 2009; 181(3): 351-358.
21. Pareek A, Godavarthi A, Issarani $R$, Nagori BP. Antioxidant and hepatoprotective activity of Fagonia schweinfurthii (Hadidi) Hadidi extract in carbon tetrachloride-induced hepatotoxicity in HepG2 cell line and rats. J Ethnopharmacol 2013; 150(3): 973-981.

22. Shen $B$, Chen $H$, Shen $C, X u P, L i J$, Shen $G$, Yuan $H$, Han J. Hepatoprotective effects of lignans extract from Herpetospermum caudigerum against $\mathrm{CCl}_{4}$-induced acute liver injury in mice. J Ethnopharmacol 2015; 164: 46-52.

23. Sadeek AE. Protective effect of fresh Juice from red beetroot (Beta vulgaris L.) and radish (Raphanus sativus L.) against carbon tetrachloride-induced hepatotoxicity in rat models. Afr J Biol Sci 2011; 7(1): 69-84.

24. Cederbaum Al. Alcohol metabolism. Clin Liver Dis 2012; 16: 667-685.

25. Abdelmegeed MA, Ha S-K, Choi Y, Akbar M, Song B-J. Role of CYP2E1 in mitochondrial dysfunction and hepatic tissue injury in alcoholic and non-alcoholic diseases. Curr Mol Pharmacol 2017; 10(3): 207-225. 